\title{
Phosphine fumigation to disinfest kiwifruit
}

\author{
L.E. Jamieson ${ }^{1}$, N.E.M Page-Weir ${ }^{1}$, A Chhagan ${ }^{1}$, D.W. Brash ${ }^{2}$, D. Klementz ${ }^{2}$, \\ B.L. Bycroft ${ }^{2}$, P.G. Connolly ${ }^{1}$, B.C. Waddell ${ }^{1}$, R. Gilbertson ${ }^{3}$, F. Bollen ${ }^{3}$ and A.B. Woolf ${ }^{1}$ \\ ${ }^{1}$ The New Zealand Institute for Plant E Food Research Limited (Plant \& Food Research), \\ Private Bag 92169, Auckland \\ ${ }^{2}$ The New Zealand Institute for Plant E Food Research Limited (Plant E Food Research), \\ Private Bag 11600, Palmerston North \\ ${ }^{3}$ ZESPRI International Ltd, PO Box 4043, Mt Maunganui \\ Corresponding author:Lisa.Jamieson@plantandfood.co.nz
}

\begin{abstract}
Global use of phosphine as a fumigant has increased in response to the need to replace methyl bromide, and with the improved formulations, $\mathrm{ECO}_{2} \mathrm{FUME}^{\circledR}$ and $\mathrm{VAPORPH}_{3} \mathrm{OS}^{\circledR}$. Phosphine is registered as a postharvest fumigant on kiwifruit in New Zealand and has been used commercially to reduce the risk of detecting live pests. Scale insects, mealybugs and diapausing twospotted spider mites were exposed to a range of phosphine treatments. A 48 -h low temperature $\left(1.7-4.6^{\circ} \mathrm{C}\right)$ fumigation $(6408-3311 \mathrm{ppm})$ achieved $100 \%$ mortality of all life stages of oleander scale insects, while a 12-h exposure killed all longtailed mealybug life stages. A 36 -h low temperature $\left(2.5-3.3^{\circ} \mathrm{C}\right)$ fumigation (4332-2712 ppm) treatment achieved $100 \%$ mortality of all greedy scale insect life stages. A 48 - to $96-\mathrm{h}$ treatment $(3600-1200 \mathrm{ppm})$ at $1-15^{\circ} \mathrm{C}$ caused $91.3-100 \%$ mortality of diapausing twospotted spider mite adults. Use of phosphine as a commercial treatment for kiwifruit is discussed.
\end{abstract}

Keywords phosphine, fumigation, low-temperature, pests, longtailed mealybug, oleander scale, greedy scale, twospotted spider mite.

\section{INTRODUCTION}

New Zealand kiwifruit are currently exported to over 60 countries worldwide and are at risk from quarantine interceptions of phytosanitary pests. Several pests commonly found on New Zealand kiwifruit, including greedy scale (Hemiberlesia rapax (Comstock)), oleander scale (Aspidiotus nerii Bouché), longtailed mealybug (Pseudococcus longispinus (Targioni-Tozzetti)) and Fuller's rose weevil (Asynonychus cervinus (Boheman)), are actionable quarantine pests for the lucrative Korean market. Mites have been intercepted on export kiwifruit entering a number of markets, including South Africa and Australia. Tuckerellid mites are the most commonly intercepted in South Africa, but oribatid and tetranychid mites have also been intercepted on fruit in this and other markets. Thrips and mealybug species can also be a problematic for New Zealand kiwifruit exports. Although some species of scale, mealybugs, thrips and mites are not quarantine pests for the target market, their immature stages may not be able to be identified and therefore quarantine inspectors must assume that they are quarantine species. 
Fruit identified as having actionable quarantine pests for designated markets require disinfestation. Treatments can be applied either as mitigation measures before fruit inspections in the source market, or on arrival if unwanted pests are detected in the destination market. Methyl bromide treatment is currently available as a treatment option where mandatory, preshipment treatment is required by the importing country. Because of the ozone-depleting nature of this fumigant, which also reduces fruit quality and shelf life, there is a movement away from its use wherever possible. This has created a significant challenge for the New Zealand kiwifruit industry, as pest-free fruit are also required for supply to other markets (e.g. Japan, Taiwan, India) and this combined with additional supply criteria (e.g. early start, taste) results in considerable logistical restraint. Cool storage is effective against scale insects (L.E. Jamieson, unpublished data) and mealybugs (Hoy \& Whiting 1996), but this is not practical for fruit that are to be marketed immediately (early supply kiwifruit), since it takes 30 days or more at a flesh temperature of $0.5^{\circ} \mathrm{C}$ or lower to achieve satisfactory mortality, and this tends to be less effective against mites (Jamieson et al. 2009).

Phosphine has been identified as a potential alternative fumigant to methyl bromide, offering a moderately fast (3 days), on-shore treatment, conducted at low temperature (e.g. $0-1{ }^{\circ} \mathrm{C}$ ) under the same conditions in which the fruit are stored for quality preservation. A new phosphine delivery system has been developed by Dr Franziskus Horn in Chile (VAPORPH $\mathrm{OS}^{\circledR}$, a pure phosphine gas formulation used in conjunction with the Horn Diluphos System (HDS) that allows pure phosphine to be applied safely by diluting the gas with air to below the spontaneous ignition concentration for phosphine of 18,000 ppm (Horn et al. 2005, 2010; Cytec 2011b). ECO FUME is also available as $2 \%$ phosphine with $98 \% \mathrm{CO}_{2}$ (Cytec 2011a). Before these innovations, phosphine in a metallic phosphide tablet form was used, which resulted in fruit phytotoxic effects and thus limited the application of phosphine to treatment of stored products (e.g. grains, dried fruit, wood products)
(Bell 2000; Bond 1984; Monro 1969). The ability to dispense pure phosphine gas safely has resulted in the re-evaluation of phosphine use on cut flowers (Karunaratne et al. 1995; Kawakami et al. 1996; Muhunthan et al. 1996; Weller et al. 1995; Weller \& Graver 1998; Williams 1995; Williams \& Muhunthan 1998) and fresh produce (Leesch 1984; Liu 2008a, b, 2009, 2011a, b; Naito et al. 2011; van Epenhuijsen et al. 2009; Soma et al. 2007; Williams et al. 2000).

Experiments to investigate the efficacy of phosphine against oleander and greedy scale insects and longtailed mealybug are presented here. With little known about the life cycle of tuckerellids, there is no published laboratory rearing technique for this group of mites. It is not currently possible to obtain the necessary large numbers of individual tuckerellid mites for mortality response trials, hence twospotted spider mite (TSM), Tetranychus urticae (Acari: Tetranychidae), was selected as a representative mite species. Therefore, the efficacy of lowtemperature phosphine against the cold-tolerant diapausing TSM lifestage was also tested.

\section{METHODS}

\section{Phosphine delivery and monitoring}

All research reported here was carried out using cylinders of phosphine gas, either $1.39 \pm 0.03 \%$ phosphine in nitrogen balance supplied by BOC Gases to mimic the commercial VAPORPH $\mathrm{OS}^{\circledR} /$ HDS system (trials 1,2\&4) or theVAPORPH ${ }_{3} \mathrm{OS}^{\circledR} /$ HDS system (commercial trial 3). The phosphine concentration was monitored $1 \mathrm{~h}$ after treatment began and 1-2 times daily during treatments (using an SRI 8610C gas chromatograph (GC) equipped with a Flame Photometric Detector (FPD) fitted with a J\&W GS-Q $30 \mathrm{~m} \times 0.53 \mathrm{~mm}$ column). Chromatography conditions were as follows: oven temperature isothermal at $100^{\circ} \mathrm{C}$, carrier gas helium at 45 psi or $30 \mathrm{ml} / \mathrm{min}, \mathrm{FPD}$ at $300^{\circ} \mathrm{C}$ and injector temperature at $250^{\circ} \mathrm{C}$. Duplicate $3-\mathrm{ml}$ samples of the gas were taken once or twice daily from each chamber throughout the fumigation treatment. If the monitored concentration fell below 20\% of the target concentration, the chamber was topped up with phosphine. 


\section{Insect and mite supply}

Oleander and greedy scale insects were reared on squash and red-skinned potatoes at $20-23^{\circ} \mathrm{C}$, 16:8 h light:dark (L:D) at Plant \& Food Research (PFR), Auckland. Longtailed mealybugs were reared on sprouting red-skinned potatoes at $20^{\circ} \mathrm{C}, 16: 8 \mathrm{~h} \mathrm{~L}: \mathrm{D}$ at PFR, Auckland.

TSM were collected from orchard sites at Clyde, Central Otago, and a colony was established at PFR Auckland on bean plants, based on methods developed by Singh \& Clare (1993). A portion of the colony was exposed to diapausing conditions (L:D $12: 12$ at $15^{\circ} \mathrm{C}$ ) during development to induce the adult to move to a black cardboard shelter $(5 \mathrm{~cm} \times 6 \mathrm{~cm})$ and enter a diapausing life stage. Cards of diapausing TSM were collected and kept for 7-24 days at $4^{\circ} \mathrm{C}$ until treatment.

Insects and mites were sent to PFR (Palmerston North) and stored at $20^{\circ} \mathrm{C}$ and $4^{\circ} \mathrm{C}$, respectively, until fumigation took place.

\section{Trial 1 - efficacy against oleander scale and longtailed mealybugs and preliminary efficacy against greedy scale}

In November 2007, oleander scale insects and longtailed mealybugs were exposed to a target of $3000 \mathrm{ppm}$ phosphine at $1^{\circ} \mathrm{C}$ (actual concentrations 6408-3311 ppm phosphine and $1.7-4.6^{\circ} \mathrm{C}$ ) in $1-\mathrm{m}^{3}$ fumigation chambers. Insect-infested potatoes were placed within trays of kiwifruit. The insect-infested potatoes were removed after $0,6,12,18,24,48$ and $72 \mathrm{~h}$ of exposure. Three to four replicate potatoes each with at least 50 insects of each life stage were treated for each duration of fumigation and compared with an untreated control. Only one replicate of greedy scale-infested potatoes was treated (and compared with an untreated control), as there were insufficient numbers of greedy scale for more. After treatment, insects were transported back to Auckland and stored at $20^{\circ} \mathrm{C}$ before assessment 7 days after fumigation.

Live and dead insects were assessed by examining the movement or physical appearance of approximately 50 insects of each life stage on each of 3-4 potatoes (from at least five sites on each potato) under a $10-50 \times$ microscope.
Mealybugs and mites were probed with a pin and, if they moved, were recorded as alive. The caps of non-mobile life stages of scale insects were removed and the scale insects were recorded as alive if they were yellow and turgid (fluidfilled). When scale insects were a dull yellow and/ or slightly flaccid to touch, the bodies were gently pulled with a fine pair of forceps and if the stylet withdrew easily or was already withdrawn, the insect was recorded as dead. If the stylet was less easily withdrawn, the insects were recorded as alive. Scale insects that were brown or flaccid or dried up were recorded as dead. Eggs that were yellow and turgid were recorded as alive.

\section{Trial 2 - efficacy against greedy scale}

In April 2008, greedy scale insects were exposed to a target rate of either $1500 \mathrm{ppm}$ or 3000 ppm phosphine at $2-3^{\circ} \mathrm{C}$ (actual 2078-1384 or 4332-2712 ppm phosphine and $2.5-4.7^{\circ} \mathrm{C}$ ) in $1-\mathrm{m}^{3}$ fumigation chambers. Potatoes infested with greedy scale were placed into single layer kiwifruit trays with polyliners, along with filler kiwifruit in trays. The infested potatoes were removed after $0,18,24$ or $36 \mathrm{~h}$ and stored at $20^{\circ} \mathrm{C}$ for 3-6 days, during which they were transported to Christchurch for assessment of insect survival using a biochemical viability test developed by AgResearch Limited (patent no. NZ555815: Method for determining the viability of an organism). Three replicate potatoes each with at least 50 second-third instar stages were treated for each concentration/duration and compared with an untreated control that was also transported.

\section{Trial 3 - commercial trial targeting greedy scale}

In July 2008, greedy scale-infested potatoes were transported to Mt Maunganui to be fumigated in a commercial facility using a 36-h exposure to $3000 \mathrm{ppm}$ phosphine (actual $1780-3163 \mathrm{ppm})$ at $2-3^{\circ} \mathrm{C}$. Greedy scale-infested potatoes (five replicate potatoes) were treated in a $59-\mathrm{m}^{3}$ container with 10 pallets of kiwifruit and 150 of the second-third instar life stages were assessed by Quality Control personnel as alive or dead 3 days later, using subjective visual 
assessment where plump = alive. Mortality was compared with that of untreated greedy scale (two replicate potatoes).

\section{Trial 4 - efficacy against diapausing twospotted mite}

In 2011 after phosphine fumigation was implemented commercially, survivors of mites were reported to be arriving on New Zealand kiwifruit in offshore markets, particularly in South Africa and Australia. Commercial treatments had been changed to a 2000-ppm concentration following a recommendation from HDS developers in Chile. As a result, three replicate fumigation trials were conducted to test the efficacy of 2000-ppm phosphine treatment against diapausing TSM at 1,7 or $15^{\circ} \mathrm{C}$ for either 48,72 or $96 \mathrm{~h}$ to determine if fumigation would be more effective at higher kiwifruit conditioning temperatures $\left(5-7^{\circ} \mathrm{C}\right)$ or at harvest temperature (ca $15^{\circ} \mathrm{C}$ ). Actual phosphine concentration ranges during the trials were 1242-2431 ppm, 1152-2615 ppm and 1109-3599 ppm in fumigations 1, 2 and 3 respectively.

Three days before the treatment began, 90 ZESPRI $^{\circledR}$ GREEN Kiwifruit were placed in 28.4-litre Labconco $^{\circledR}$ chambers, which were subsequently put inside $1-\mathrm{m}^{3}$ controlled temperature chambers. There were 1-3 Labconco ${ }^{\circledR}$ chambers per controlled temperature chamber. Fruit inside the Labconco ${ }^{\circledR}$ chambers were cooled to either 1,7 or $15^{\circ} \mathrm{C}$ at $24 \mathrm{~h}$ before treatment began. Kiwifruit loading for each chamber was kept constant, at about $56 \%$ of chamber volume (90 kiwifruit).

Diapausing adult TSM on cardboard were collected into ventilated containers, transported to Palmerston North overnight and stored for a further 3 days at $4^{\circ} \mathrm{C}$ before treatment. Between 102 and 424 diapausing adult mites were treated for each replicate/duration/temperature combination. After treatment, mites were kept at $20^{\circ} \mathrm{C}$ before and after being transported back to Auckland until assessment 5 days after treatment. In the first two fumigations, mites were classified as alive (movement) and dead (no movement) after prodding with a pin. In the third, it was noted that after prodding, live mites walked away immediately and dead mites did not move at all. However, there were a number of phosphinetreated 'moribund' mites that twitched a leg when prodded but seemed incapable of walking. These moribund mites were functionally dead because without the ability to walk, they would probably not contribute further to a reproducing population and therefore could be classified as 'dead'. However, if intercepted, a quarantine inspector would classify these moribund mites as alive.

\section{Statistical analysis}

For mortality response figures (Figures 1,2 and 3), the loess smoothing function (Chambers \& Hastie 1992) was used in $R$ ( $R$ Development Core Team 2009) to draw a smooth line through the mean mortality points for each pest after exposure to different phosphine treatments at each exposure time. An $\arcsin$ transformation $(\arcsin (\operatorname{sqrt}(\mathrm{p})))$ was applied to the percentage (p) to stabilise the variance (i.e. so that the error bar is appropriated over the entire range of 1-100\%). Standard errors for each treatment were calculated at every treatment time or dose. The root mean square of these SEMs gave a mean SEM for each life stage at each storage temperature.

\section{RESULTS}

Trial 1 - efficacy against oleander scale and longtailed mealybugs and preliminary efficacy against greedy scale

Figure 1 shows the mortality response of oleander scale to low-temperature phosphine fumigation. Late third instar oleander scale (or adults) were the most tolerant stage and complete mortality occurred between 24 and $48 \mathrm{~h}$ of exposure to low temperature phosphine fumigation using "3000 ppm" (actual phosphine concentration 6408 ppm-3137 ppm at 0-48 h respectively).

Mealybugs were more susceptible than oleander scale to fumigation and were killed in $18 \mathrm{~h}$ when exposed to the conditions given above (Figure 2).

The efficacy of low temperature phosphine against greedy scale suggests that they can be killed with a 24-h treatment (Figure 3). 


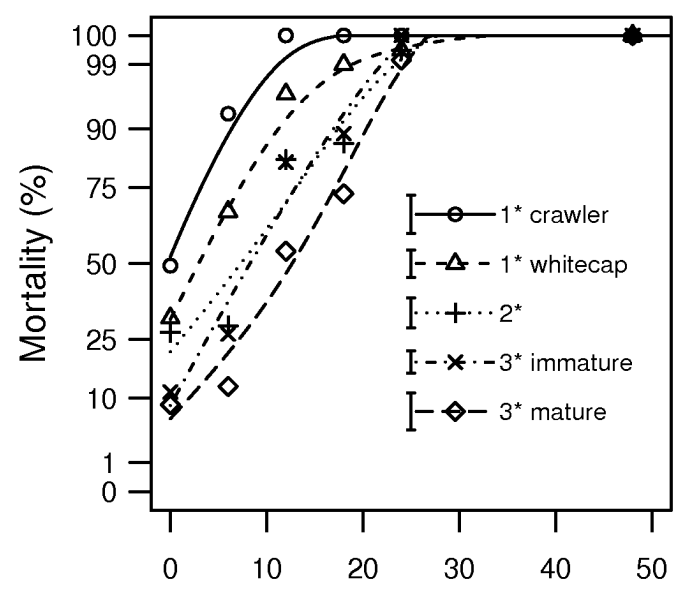

Hours of phosphine fumigation

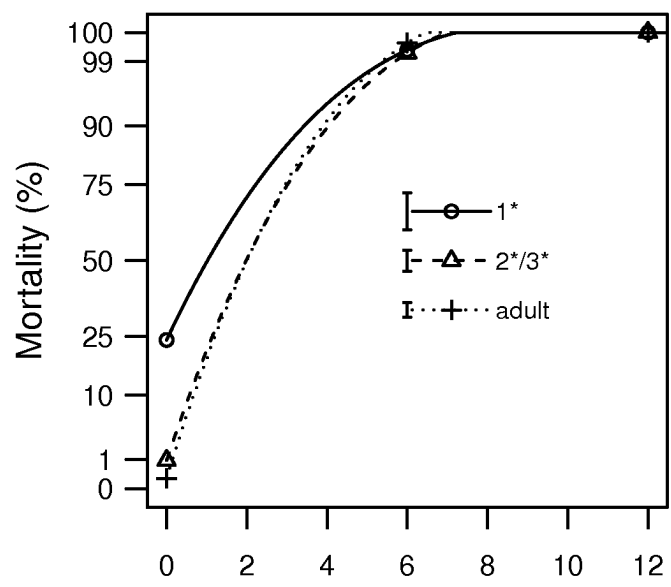

Hours of phosphine fumigation

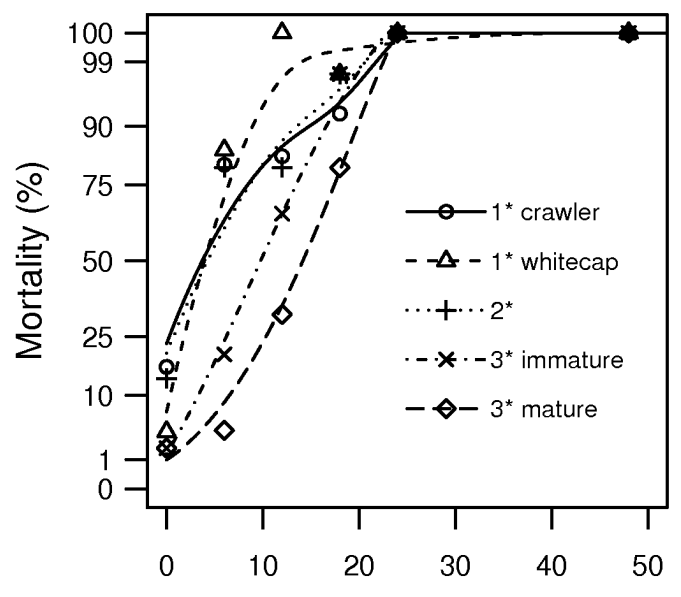

Hours of phosphine fumigation
Figure 1 Percentage mortality of different life stages of oleander scale, Aspidiotus nerii, 7 days after fumigation with $3000 \mathrm{ppm}$ phosphine at $1^{\circ} \mathrm{C}$ (actual values 6408-3311 ppm phosphine and 1.7$\left.4.6^{\circ} \mathrm{C}\right)(\mathrm{n}=200$ insects per point $) .1^{\star}, 2^{\star}, 3^{\star}=$ first instar, second instar, third instar, respectively.

Figure 2 Percentage mortality of different life stages of longtailed mealybug, Pseudococcus longispinus, 7 days after fumigation with $3000 \mathrm{ppm}$ phosphine at $1^{\circ} \mathrm{C}$ (actual values 64083311 ppm phosphine and $\left.1.7-4.6^{\circ} \mathrm{C}\right) \quad(\mathrm{n}=200$ insects per point). $1^{\star}, 2^{\star}, 3^{\star}=$ first instar, second instar, third instar, respectively.

Figure 3 Percentage mortality of different life stages of greedy scale, Hemiberlesia rapax, 7 days after fumigation with $3000 \mathrm{ppm}$ phosphine at $1^{\circ} \mathrm{C}$ (actual values 6408-3311 ppm phosphine and 1.7$\left.4.6^{\circ} \mathrm{C}\right)(\mathrm{n}=50$ insects per point $) .1^{\star}, 2^{\star}, 3^{\star}=$ first instar, second instar, third instar, respectively. 


\section{Trial 2 - efficacy against greedy scale}

The second trial indicated that $36 \mathrm{~h}$ was required to kill all second and third instar greedy scale (Table 1) using a nominal dose of $3000 \mathrm{ppm}$ at $2-3^{\circ} \mathrm{C}$ (actual concentrations 4332-2712 ppm phosphine and $2.5-3.3^{\circ} \mathrm{C}$ ). Survivors were found after a 24-h exposure to ca $3000 \mathrm{ppm}$ and also in the lower dose treatments at ca $1500 \mathrm{ppm}$ (actual concentrations 2078-1384 ppm).

\section{Trial 3 - commercial trial targeting greedy scale} The efficacy of the 36-h 3000-ppm treatment at $2-3^{\circ} \mathrm{C}$ against greedy scale was confirmed in trial 3 (commercial trial) (Table 2) when 100\% mortality of greedy scale insects $(n=150$ at second-third instar life stage) was achieved compared with $31.3 \%$ mortality of untreated greedy scale insects.

\section{Trial 4 - efficacy against diapausing twospotted mite}

Trial 4, examining the efficacy of the adjusted commercial treatment of $2000 \mathrm{ppm}$ phosphine at $2-3^{\circ} \mathrm{C}$ (Table 2 ), showed that when including moribund mites as dead, phosphine treatment (actual concentrations ranged from 1109 $3599 \mathrm{ppm}$ ) resulted in more than $99 \%$ mortality of mites regardless of treatment temperature and time, compared with $6-11 \%$ mortality of untreated mites and 7-20\% mortality of mites kept at 1,7 or $15^{\circ} \mathrm{C}$ for $96 \mathrm{~h}$. Live mites were present in all 48 -h treatments, 1 live TSM was found in the 72-h treatments, and none in the 96-h treatments. However, there was not a sufficient range in mortality response data to conduct statistical analyses to establish the effect of increasing time or temperature.

Table 1 Mean percentage mortality (mean \pm standard error) of second and third instar greedy scale (Hemiberlesia rapax) at 3-6 days after fumigation with nominal doses of $1500 \mathrm{ppm}$ or $3000 \mathrm{ppm}$ phosphine at $2-3^{\circ} \mathrm{C}$ (actual concentrations 2078-1384 ppm or 4332-2712 ppm phosphine and $\left.2.5-4.7^{\circ} \mathrm{C}\right) . \mathrm{n}=$ the number of specimens tested.

\begin{tabular}{|c|c|c|c|c|c|c|c|}
\hline \multirow{2}{*}{$\begin{array}{l}\text { Phosphine } \\
\text { dose }\end{array}$} & \multirow{2}{*}{$\begin{array}{l}\text { Duration } \\
\text { (h) }\end{array}$} & \multicolumn{2}{|r|}{ Total } & \multicolumn{2}{|r|}{ 2nd instar } & \multicolumn{2}{|r|}{ 3rd instar } \\
\hline & & $\mathrm{n}$ & Mortality (\%) & $\mathrm{n}$ & Mortality (\%) & $\mathrm{n}$ & Mortality (\%) \\
\hline $0 \mathrm{ppm}$ & 0 & 150 & $14.7 \pm 3.7$ & 55 & $24.3 \pm 14.5$ & 95 & $5.6 \pm 3.6$ \\
\hline \multirow[t]{3}{*}{1500 ppm } & 18 & 150 & $46.7 \pm 7.5$ & 68 & $45.1 \pm 7.4$ & 82 & $47.7 \pm 7.8$ \\
\hline & 24 & 150 & $91.3 \pm 2.4$ & 74 & $89.2 \pm 3.7$ & 76 & $94.8 \pm 3.3$ \\
\hline & 36 & 150 & $97.3 \pm 1.3$ & 73 & $95.4 \pm 2.4$ & 77 & 100 \\
\hline \multirow[t]{3}{*}{3000 ppm } & 18 & 150 & $70.0 \pm 6.4$ & 96 & $71.1 \pm 6.9$ & 54 & $67.7 \pm 5.9$ \\
\hline & 24 & 150 & $92.7 \pm 4.4$ & 60 & $88.4 \pm 3.7$ & 90 & $95.4 \pm 4.6$ \\
\hline & 36 & 150 & 100 & 43 & 100 & 107 & 100 \\
\hline
\end{tabular}

Table 2 The mean percentage mortality of diapausing twospotted spider mites after phosphine treatment at ca $2000 \mathrm{ppm}$, at three durations and three temperatures and one standardised chamber load. (N.B. moribund was counted as dead, except for the percentage mortality data in parentheses). $\mathrm{n}=539-811$ mites for each time/temperature combination.

\begin{tabular}{|c|c|c|c|c|}
\hline \multirow[b]{2}{*}{$\begin{array}{l}\text { Duration } \\
\text { (h) }\end{array}$} & \multicolumn{4}{|c|}{ Temperature $\left({ }^{\circ} \mathrm{C}\right)$} \\
\hline & 1 & 7 & 15 & $\begin{array}{c}20 \text { (Handling } \\
\text { control, } 0 \text { ppm) }\end{array}$ \\
\hline 0 & 20.2 & 13.4 & 6.7 & \\
\hline 48 & $99.9(96.7)$ & $99.3(92.9)$ & $99.3(95.2)$ & 11.3 \\
\hline 72 & 100 & 100 & 99.8 & 5.8 \\
\hline 96 & $100(91.3)$ & $100(97.5)$ & $100(99.4)$ & 10.6 \\
\hline
\end{tabular}




\section{DISCUSSION}

The results show that a low temperature $\left(1-3^{\circ} \mathrm{C}\right)$ phosphine treatment using ca $3000 \mathrm{ppm}$ for $36 \mathrm{~h}$ was effective in providing control of oleander scale, longtailed mealybug and greedy scale. This information was used to register phosphine for use against scale insects and mites on kiwifruit. After commercial treatments began, problems with controlling mites became evident (particularly oribatid and tuckerellid mites (F. Bollen, unpublished data). The concentration of phosphine in commercial treatments by this time had been decreased from $3000 \mathrm{ppm}$ to $2000 \mathrm{ppm}$ and the time extended to $96 \mathrm{~h}$ for kiwifruit going to 'mite sensitive' markets. Testing the efficacy of $2000 \mathrm{ppm}$ phosphine against diapausing TSM as a representative of a 'hardto-kill' mite highlighted issues with moribund pests being found on phosphine-treated fruit. Moribund insects have also been found in phosphine trials to kill burnt pine longhorn beetle adults (S. Wimalaratne, unpublished data) and codling moth larvae (D. Rogers, unpublished data). Whether or not such moribund organisms should be classified as live or dead remains unknown, although codling moth larvae have continued show some responses for many weeks. In the absence of scientific data demonstrating that moribund pests are unable to reproduce, phytosanitary inspectors will not await the outcome of delayed mortality and will determine moribund larvae as alive. The commercial treatment of $2000 \mathrm{ppm}$ for $96 \mathrm{~h}$ at $1^{\circ} \mathrm{C}$ would reduce the risk of live diapausing TSM being detected on kiwifruit. However, further research is required to test the efficacy of phosphine against tuckerellid and oribatid mites and to develop an acceptable treatment. The issue of moribund insects is not unsolvable, and adequate laboratory data could be produced to show that insects found in phosphine-treated fruit and classed as 'moribund' are effectively dead.

Associated kiwifruit quality research showed that a $24-$ or $72-\mathrm{h}$ phosphine treatment at $0-1^{\circ} \mathrm{C}$ had no negative impact on the quality of stored kiwifruit when applied at the lower rate of 1000 $\mathrm{ppm}$, but caused a slight reduction in quality when applied at the higher rate of 3000 ppm, mainly because of an increase in disorders such as low temperature breakdown (R. Jackman, unpublished data). Subsequent work on freshly harvested rather than already cool-stored kiwifruit showed no significant reduction in fruit quality after a $36-\mathrm{h}$ $3000 \mathrm{ppm}$ phosphine treatment at low temperature, although there was some increased softening (R. Feng, unpublished data). However, kiwifruit commercially treated with phosphine using 2000 ppm for $96 \mathrm{~h}$ at $1^{\circ} \mathrm{C}$ have resulted in quality issues after arrival in market and have had a distinct metallic/chemical aroma (A. Woolf, unpublished data). Phosphine residues have not been an issue, with phosphine in treated kiwifruit being below the maximum residue level (MRL) of $0.002 \mathrm{mg} / \mathrm{kg}$ within 1-2 days (L.E. Jamieson \& F. Bollen, unpublished data).

$\mathrm{VAPORPH}_{3} \mathrm{OS}^{\circledR}$, the pure phosphine gas formulation used in conjunction with the Horn Diluphos System, is now registered for use against pests of cut flowers, apples and kiwifruit in New Zealand. Internationally, there seems to be a disconnection between research on phosphine fumigation for perishables, actual commercialisation of phosphine treatments based on research, and any cohesive efforts to approve phosphine fumigations as a disinfestation treatment on a regulatory basis (J. Armstrong, unpublished review). Global use of phosphine has increased dramatically, especially with the development of $\mathrm{ECO}_{2} \mathrm{FUME}^{\circledR}$ and VAPORPH ${ }_{3} \mathrm{OS}^{\circledR}$, and with the need to replace methyl bromide. To date, phosphine treatments have been used on fresh produce in order to mitigate the risk of pest detection. Currently there is no known approved phosphine fumigation treatment schedule for fresh produce on an official regulatory basis.

\section{ACKNOWLEDGEMENTS}

Thanks to Ilia Iline and Craig Phillips, AgResearch, for assistance with assessments using the biochemical viability test; also to Mano Sandanayaka, Plant \& Food Research, for assistance with assessments. Thanks to Jack Armstrong, Quarantine Scientific, who recently completed a review of phosphine for fresh produce. 


\section{REFERENCES}

Bell CH 2000. Fumigation in the $21^{\text {st }}$ century. Crop Protection 19 (8/10): 563-569.

Bond EJ 1984. Manual of fumigation for insect control. FAO Plant Production and Protection Paper 54. UN FAO, Rome, Italy. Reprinted 1989. $351 \mathrm{p}$.

Chambers JM, Hastie TJ 1992. Statistical Methods. S. Wadsworth \& Brooks/Cole Advanced Books \& Software, Pacific Grove, CA, USA. 608 p.

Cytec2011a. Eco fume $^{\circledR}$ Product Data Sheet.http:// www.cytec.com/specialty-chemicals/PDFs/ AgriculturalFumigation/EcofumeDatasheet. pdf [accessed 2 April 2012].

Cytec 2011b. VAPORPH $\mathrm{OS}^{\circledR}{ }^{\circledR}$ Phosphine Fumigant Onsite Blending with Air. Product Data Sheet, SPT-169-B-EN-WW-02C. https:// www.cytec.com/specialty-chemicals/PDFs/ AgriculturalFumigation/VAP\%20On \%20 Site\%20Air.pdf [accessed 11 May 2012].

Horn FF, Horn FP, Horn PP, Horn JP, Diaz RM 2005. Fosfoquim S.A., assignee 2005-1201 . Procedure of fumigation with a high concentration of pure phosphine free from ammonia at low temperature for the control of pests in fruits without damaging its quality. US Patent No. US25265892.

Horn P, Horn F, Tumambing J, Rogers M 2010. Studies and commercial application of Vaporph $\mathrm{Vs}_{3}$ phosphine fumigant for disinfestation of exported fruits and vegetables in South America. Acta Horticulturae 880: 407-414.

Hoy LE, Whiting DC 1996. Low-temperature storage as a postharvest treatment to control Pseudococcus affinis (Maskell) on Royal Gala apples. Journal of Economic Entomology 90(5): 1377-1381.

Jamieson LE., Meier X., Page B, Zulhendri F, PageWeir N, Brash D, McDonald RM, Stanley J, Woolf $\mathrm{AB}$ 2009. A review of postharvest disinfestation technologies for selected fruits and vegetables. Plant \& Food Research Client Report 36072. Plant \& Food Research, Auckland, New Zealand. 183 p.

Karunaratne C, Moore GA, Jones RB, Ryan RF 1995. Evaluation of phosphine as a disinfestation treatment for some common insects in cut flowers. Proceedings Australasian Postharvest Horticulture Conference, 18-22 September 1995, Monash University, Victoria, Australia. Pp. 359-366.

Kawakami F, Soma Y, Tsutsumi T, Sato T, Yuge T, Yamamoto M, Komatsu H, Inoue T 1996. Disinfestation of pests on cut flowers with gas mixtures of methyl bromide, phosphine and carbon dioxide. Research Bulletin Plant Protection Japan 32: 39-46.

Leesch JG 1984. Fumigation of lettuce: Efficacy and phytotoxicity. Journal of Economic Entomology 77: 142-150.

Liu YB. 2008a. Advances in postharvest pest control on perishable commodities using ultralow oxygen treatment and low temperature phosphine fumigation. In: Proceedings of the $8^{\text {th }}$ International Conference on Controlled Atmosphere and Fumigation in Stored Products, 21-26 September 2008, Chengdu, China. Sichuan Publishing House of Science and Technology, Chengdu, China. 738 p.

Liu YB 2008b. Low temperature phosphine fumigation for postharvest control of western flower thrips (Thysanoptera: Thripidae) on lettuce, broccoli, asparagus, and strawberry. Journal of Economic Entomology 101: 1786-1791.

Liu YB. 2009. Low temperature phosphine fumigation for postharvest pest control on fresh vegetables. Proceedings of International Research Conference on Methyl Bromide Alternatives, San Diego, California, USA. 29 October-1 November 2009. 84-1, 84-2.

Liu YB 2011a. Low-temperature phosphine fumigation of chilled lettuce under insulated cover for postharvest control of western flower thrips, Frankliniella occidentalis (Pergande) (Thysanoptera: Thripidae). Journal of AsiaPacific Entomology 14(3): 323-325.

Liu YB 2011b. Oxygen enhances phosphine toxicity for postharvest pest control. Journal of Economic Entomology 104(5): 1455-1461. 
Monro HAU 1969. Manual of fumigation for insect control (second edition, revised). Food and Agriculture Organization of the United Nations, Study No. 79. FAO, Rome. $381 \mathrm{p}$.

Muhunthan M, Williams P, Thorpe GR 1996. Phosphine - an alternative to methyl bromide for postharvest disinfestation of wildflowers in containers. Agricultural Engineering Australia 26: 29-33.

Naito H, Aoki M, Yamada K 2011. Studies on tolerance of fresh vegetables to methyl iodide, sulfuryl fluoride and phosphine fumigation. Research Bulletin Plant Protection Japan 47: 49-55.

Singh P, Clare GK 1993. A method for continuous production of diapausing twospotted mite in the laboratory. New Zealand Entomologist 16: 94-99.

Soma Y, Ogawa N, Tanigawa N, Kawakami F 2007. Quality tolerance of fresh fruits and vegetables to methyl iodide and phosphine fumigation. Research Bulletin Plant Protection Japan 43: 1-7.

van Epenhuijsen CW, Wimalaratne SK, Somerfield KG, Hedderley DI, Page BBC, Brash DW. 2009. Control of onion thrips adults and eggs with phosphine. New Zealand Plant Protection 62: 400 (abstract only).

Weller GL, Graver JE van S 1998. Cut flower disinfestation: assessment of replacement fumigants for methyl bromide. Postharvest Biology and Technology 14(3): 325-333.

Weller GL, Graver JE van S, Damcevski KA 1995. Replacements for methyl bromide in quarantine treatments of cut flowers and ornamentals. Proceedings of Australasian Postharvest Horticulture Conference, 18-22 September 1995. Melbourne, Australia. Pp. 366-372.

Williams P 1995. Alternatives to methyl bromide for fumigation of wildflowers. Proceedings of Australasian Postharvest Horticulture Conference, Melbourne, Australia, 18-22 September 1995. Pp. 373-376.

Williams P, Muhunthan M 1998. Fumigants for postharvest control of insect pests of cut flowers. Acta Horticulturae 464: 291-296.

Williams P, Hepworth G, Goubran F, Muhunthan M, Dunn K 2000. Phosphine as a replacement for methyl bromide for postharvest disinfestation of citrus. Postharvest Biology and Technology 19(2): 193-199. 